\title{
DETEKSI TINGKAT KERUSAKAN SISTEM KELISTRIKAN PADA MOBIL MENGGUNAKAN ADAPTIVE NEURO-FUZZY INFERENCE SYSTEM
}

\author{
Rizky Prabowo ${ }^{*}$, Zuliana Nurfadlilah ${ }^{2}$, Favorisen Rosyking Lumbanraja3 ${ }^{3}$, Didik \\ Kurniawan 4 \\ 1,2,3,4 Jurusan Ilmu Komputer, \\ Fakultas Matematika dan Ilmu Pengetahuan Alam, \\ Universitas Lampung \\ *e-mail koresponden: rizky.prabowo@fmipa.unila.ac.id
}

\begin{abstract}
The automotive industry in Indonesia has significant increase in the past decade. A famous car company opened a manufacturing branch to increase its production capacity in Indonesia. An increase in sales is directly proportional to an increase in service to customers. Damage on electrical system is the majority of modern car. Unfortunately, car users have minimal knowledge of car electricity. This article describes the technique of detecting the level of damage to a car's electrical system using the Adaptive Neuro-Fuzzy Inference System (Anfis) concept. As a case study in designing the system in question is the electrical system on the Toyota Avanza. Formation of a fuzzy inference system which is used for the system formation process through a GUI-based interface design (Graphic User Interface). The output of the system is a fuzzy analysis based on the membership function of the Gaussian, Triangular and Trapezoid methods to obtain an analysis of the level of damage to the electrical system on a Toyota Avanza. From the results of the system test for starter system, firewire system and lighting system, it is concluded that the analysis of the level of damage to the electrical system on the car using Anfis based on the Gaussian membership function model is more accurate(reach 85\%) in predicting the level of damage to the analyzed electrical system.
\end{abstract}

Keywords: Anfis, Electrical System, Fuzzy Inference System, Toyota Avanza

\section{Abstrak}

Industri otomotif di Indonesia mengalami peningkatan signifikan dalam kurun waktu satu dekade belakangan ini. Perusahaan mobil terkenal membuka pabrik manufaktur untuk meningkatkan kapasitas produksinya di Indonesia. Peningkatan penjualan berbanding lurus dengan peningkatan layanan kepada pelanggan. Kerusakan sistem kelistrikan merupakan kerusakan yang mayoritas dialami pengguna kendaraan mobil terbaru masa kini. Sayangnya, pengguna kendaraan mobil memiliki pengetahuan yang kurang tentang kelistrikan. Artikel ini mendeskripsikan tentang teknik mendeteksi tingkat kerusakan sistem kelistrikan mobil dengan menggunakan konsep Adaptive Neuro-Fuzzy Inference System (ANFIS). Sebagai studi kasus dalam mendesain sistem yang dimaksud adalah sistem kelistrikan pada Mobil Toyota Avanza. Pembentukan fuzzy inference system yang kemudian digunakan untuk proses pembentukan sistem melalui desain interface 
berbasis GUI (Graphic User Interface). Keluaran dari sistem yang dibuat adalah analisa fuzzy berdasarkan fungsi keanggotaan metode Gaussian, Triangular dan Trapezoid untuk mendapatkan analisa tingkat kerusakan sistem kelistrikan pada mobil Toyota Avanza. Dari hasil uji sistem yang dilakukan pada sistem starter, sistem pengapian dan sistem penerangan diperoleh kesimpulan analisis tingkat kerusakan sistem kelistrikan pada mobil dengan menggunakan Anfis berdasarkan model membership function Gaussian adalah lebih akurat (mencapai 85\%) dalam menduga tingkat kerusakan sistem kelistrikan yang dianalisa.

Kata kunci: Anfis; Fuzzy Inference System; Sistem Kelistrikan; Toyota Avanza

\section{PENDAHULUAN}

Perkembangan industri otomotif di Indonesia dirasakan telah meningkat sangat pesat. Ini dapat dilihat dari banyaknya perusahaan mobil terkenal membuka pabrik manufaktur atau meningkatkan kapasitas produksinya di Indonesia. Berdasarkan data yang terdapat pada CNN Indonesia [1] dari bulan Januari hingga Mei 2018 penjualan domestik berjumlah 494.778 unit. Informasi yang diberikan dalam Gambar 1, selama lima bulan, Toyota menjual 143.440 unit, diikuti dengan Mitsubishi 90.146 unit, Daihatsu 88.209 unit, Honda 67.598 unit, dan lain-lain. Salah satu jenis mobil dari Toyota yang saat ini tingkat penjualannya tinggi adalah Toyota Avanza. Pengaruh faktor budaya, faktor sosial, faktor karakteristik individu dan faktor psikologis yang mempengaruhi penjualan pada Toyota Avanza ini meningkat di pasaran [2]. Toyota meluncurkan Toyota Avanza pada tahun 2003 karena keprihatinan atas lambatnya pertumbuhan penjualan Toyota Kijang setelah melakukan riset pasar menyeluruh untuk memenuhi kebutuhan spesifik pelanggan Indonesia. [3]

Permasalahan yang sering ditemukan di masyarakat pengguna mobil adalah kerusakan sistem kelistrikan mobil. Pada prinsipnya ada beberapa jenis kerusakan yang dapat dijumpai pada sebuah mobil. Namun kerusakan sistem kelistrikan ini sering dijumpai pada mobil-mobil masa kini yang sudah menggunakan sistem digitalisasi. Bila sistem kelistrikan dapat diatasi, akan memberikan manfaat untuk mengurangi emisi gas rumah kaca dan paparan emisi knalpot pada kendaraan [4]. Selain itu, manfaat yang dirasakan dapat mengurangi penggunaan bahan bakar fosil, dan memungkinkan sumber energi terbarukan untuk transportasi [5]. Dampak negatif dari sistem kelistrikan yang buruk pada sebuah mobil adalah kebocoran kabel busi. Kebocoran kabel busi tersebut dapat menyebabkan konslet pada kendaraan yang kemudian mengeluarkan api diantara kabel busi dan ground sehingga menyebabkan kebakaran. 


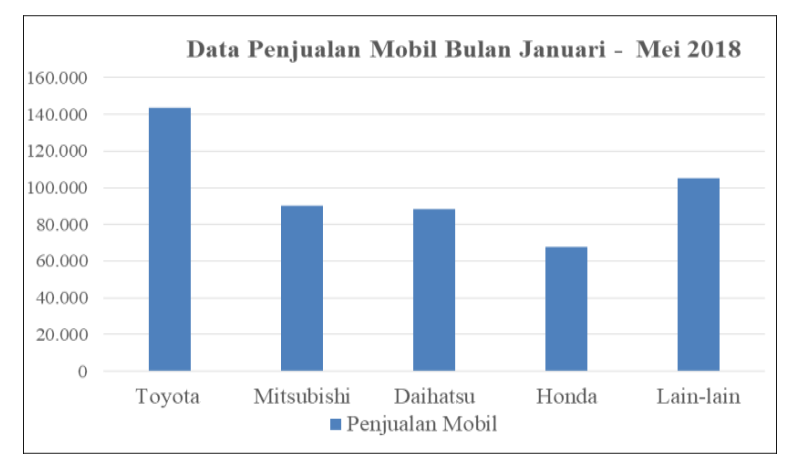

Gambar 1. Data Penjualan Mobil dari Bulan Januari - Mei 2018 [1].

Beberapa konsep dasar tentang sistem pakar menjadi acuan sistem informasi yang dibangun dalam penelitian yang dilakukan. Sebagaimana diketahui bahwa sistem pakar (expert system) merupakan sebuah sistem yang kinerjanya meniru/mengadopsi keahlian yang dimiliki seorang pakar dalam bidang tertentu ke dalam sebuah sistem atau program komputer yang dapat digunakan oleh pengguna yang bukan seorang pakar sehingga diperoleh sebuah keputusan layaknya seorang pakar (Gambar 2) [6] [7] [8].

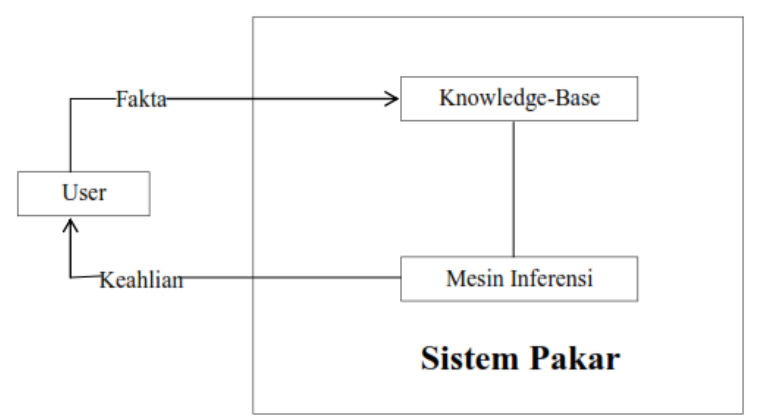

Gambar 2. Konsep dasar sistem pakar [6].

Penelitian berkenaan dengan sistem informasi kepakaran harus berupa sistem informasi yang dibuat dan dibutuhkan bagi pengguna untuk meningkatkan ketersediaan kepakaran atau keahlian berupa sebuah sistem komputer, mengurangi biaya jasa seorang pakar, lebih permanen dalam hal eksistensi ilmu pengetahuan, dan lebih rinci dalam penjelasan hingga diperoleh kesimpulan yang meyakinkan [7]. Selain itu beberapa komponen program sistem informasi yang disarankan mutlak harus ada komponen basis pengetahuan, basis data, dan mesin inferensi [8]. Selain hal penting dalam membuat sistem kepakaran adalah metode pendekatan dalam membangun sistem informasi. Dalam hal ini pendekatan secara matematis menggunakan konsep logika kabur (fuzzy logic) dapat menjadi opsi dalam penelitian yang dilakukan.

Pada prinsipnya fuzzy logic merupakan suatu teori himpunan logika yang dikembangkan untuk mengatasi konsep nilai yang terdapat diantara kebenaran (true) dan kesalahan (false). Contoh penerapan fuzzy logic pada aplikasi pengontrol suhu ruangan, prediksi cuaca, dan pengelolaan keuangan. Konsep logika fuzzy 
dapat mudah dipahami karena kesederhanaannya [9]. Terdapat beberapa alasan untuk menggunakan logika fuzzy, yaitu mudah dimengerti dan fleksibel, sederhana, memiliki toleransi terhadap data-data yang tidak tepat, mampu memodelkan fungsi-fungsi non-linear yang sangat kompleks, dapat membangun dan mengaplikasikan pengalaman-pengalaman para pakar secara langsung tanpa harus melalui proses pelatihan, dapat bekerjasama dengan teknik-teknik kendali secara konvensional, dan berdasarkan bahasa alami [10]. Salah satu penggunaan logika fuzzy yang cukup dikenal adalah Fuzzy Inference System/ FIS. FIS merupakan kerangka komputasi yang didasarkan pada teori himpunan fuzzy, aturan fuzzy berbentuk IF-THEN dan penalaran fuzzy. Salah satu teknik inferensi fuzzy yang umum digunakan adalah metode Mamdani [11]. Dalam metode Mamdani terdapat 4 (empat) tahapan dalam melakukan proses terhadap variabel input yaitu Fuzzification, Rule Evaluation, Rule Agregation, dan Defuzzification. Metode Mamdani memiliki 3 (tiga) fungsi keanggotaan yaitu fungsi keanggotaan yang direpresentasikan oleh kurva Gaussian, segitiga, dan trapesium [12].

Beberapa hasil penelitian terkait dengan sistem pakar, misalnya [13] yang telah melakukan penelitian untuk mendiagnosa penyakit hipertiroid melalui metode inferensi fuzzy mamdani. Dalam penelitian tersebut mereka memberikan input berupa skor gejala, dan hasil pemeriksaan darah berupa TSH dan kadar TF4 dang menghasilkan output berupa hasil diagnosa diperoleh akurasi sebesar 95,45\%. Selain itu, penggunaan sistem pakar juga dilakukan pada penelitian untuk mengetahui hasil perbandingan jumlah membership dan model Fuzzy terhadap perubahan suhu pada inkubator penetas telur [14]. Dalam penelitian tersebut digunakan 3 jenis membership function, yaitu Gaussian, Trapezoid, dan Triangle. Hasilnya adalah diperoleh rata-rata waktu untuk mencapai kondisi ideal dari suhu awal 35 derajat celcius adalah 36,67 - 41,67 detik.

Pada saat ini belum ada sistem pakar yang spesifik ke satu jenis mobil (Avanza tipe $\mathrm{S}$ kapasitas $1.500 \mathrm{cc}$ ). Pada penelitian ini dibangung sebuah sistem pakar deteksi masalah kelistrikan pada jenis mobil tersebut.

\section{METODOLOGI PENELITIAN}

Cara menyelesaikan masalah dalam penelitian yang dilakukan meliputi sejumlah langkah-langkah yaitu:

a. Studi/observasi literatur: Pada tahapan ini dilakukan pengumpulan dan kajian sejumlah referensi berkenaan dengan kendaraan mobil dan metode penyelesaian masalah berbasis sistem pakar.

b. Pembatasan masalah: Dalam hal ini jenis kerusakan yang akan di deteksi adalah kerusakan sistem kelistrikan pada Avanza tipe S kapasitas 1.500 cc.

c. Pengumpulan data (lapangan): Berdasarkan dua langkah sebelumnya dipilih studi kasus terhadap Toyota Avanza. Pengumpulan data kendaraan tersebut dilakukan di dealer resmi Toyota yakni Auto 2000 yang terletak di jalan Raden Intan Bandar Lampung dengan supervisor lapangan (Pakar) 
d. Pembuatan Model Sistem Pakar: Dari data yang diperoleh dilakukan identifikasi kerusakan dan gejala-gejala yang dialami untuk kemudian dibuat rule koneksi dan sistem pakar berbasis teknologi informasi menggunakan perangkat lunak MATLAB R2012b. Adapun tahapan penelitian yang dilakukan diperlihatkan dalam Gambar 3.

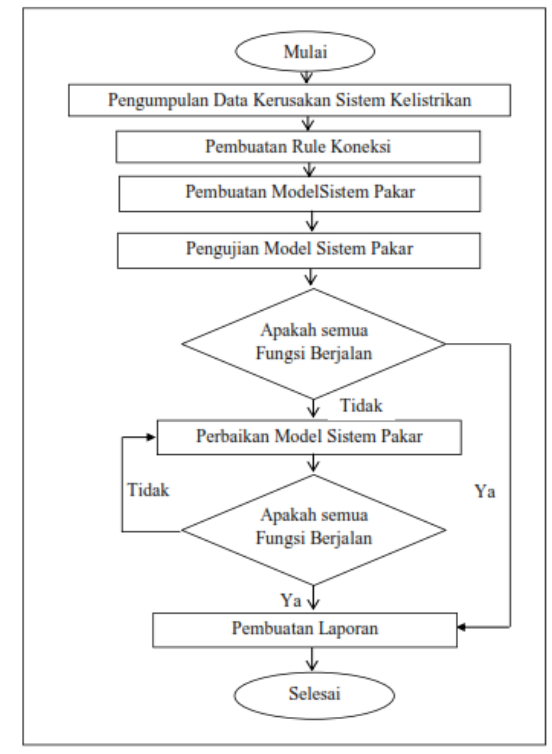

Gambar 3. Tahapan penelitian

e. Pengujian Model: Pengujian model dimaksudkan adalah melakukan pengujian sistem serta perbaikan sistem yang dilandasi pada informasi yang diberikan Pakar dan output yang diberikan sistem pakar.

\section{HASIL DAN PEMBAHASAN}

\subsection{Identifikasi Kerusakan Sistem Kelistrikan pada Mobil Toyota Avanza}

Pengumpulan data kerusakan sistem kelistrikan pada penelitian yang dilakukan adalah dengan mengumpulkan data dari repair manual Toyota Avanza.

\subsection{Klasifikasi Kerusakan Sistem Kelistrikan Pada Mobil Toyota Avanza}

Dalam sistem kelistrikan kendaraan mobil terdapat beberapa kalsifikasi kerusakan. Dalam sistem pakar yang dibuat ada 10 jenis klasifikasi kerusakan yang dimaksud diberikan dalam Tabel 1.

Tabel 1. Daftar Klasifikasi Kerusakan Sistem Kelistrikan pada Mobil Toyota Avanza

\begin{tabular}{cccc}
\hline No. & Jenis Kerusakan & No. & Jenis Kerusakan \\
\hline 1. & Meter/ Gauge & 6. & Window \\
2. & Audio & 7. & Mirror \\
3. & Door Lock & 8. & Wiper/Washer \\
4. & Lighting Interior & 9. & Lighting Exterior \\
5. & AC/ Air Conditioner & 10. & Horn \\
\hline
\end{tabular}




\subsection{Nama dan Kode Gejala Kerusakan Sistem Kelistrikan}

Terdapat beberapa gejala kerusakan sistem kelistrikan untuk masingmasing klasifikasi kerusakan pada sistem kelistrikan kendaraan mobil yang diberikan dalam Tabel 1. Pada kerusakan Meter/Gauge memiliki 16 gejala, kerusakan Audio memiliki 13 gejala, kerusakan Door Lock memiliki 5 gejala, kerusakan Lighting Interior memiliki 4 gejala, kerusakan AC/ Air Conditioner memiliki 7 gejala, kerusakan Window memiliki 6 gejala, kerusakan Wiper/ Washer memiliki 9 gejala, kerusakan Mirror memiliki 2 gejala, kerusakan Lighting Exterior memiliki 23 gejala, kerusakan Horn memiliki 1 gejala.

\subsection{Rule Koneksi}

Rule koneksi merupakan hal penting dalam desain sistem pakar. Rule koneksi dikonstruksi berdasarkan banyaknya gejala pada masing-masing klasifikasi kerusakan sistem kelistrikan. Banyaknya rule koneksi yang terjadi dikalkulasi dengan menggunakan formula $2^{\mathrm{n}}$ dengan $\mathrm{n}=$ banyaknya gejala. Oleh karena itu untuk masing-masing klasfikasi kerusakan yang ada pada sistem dapat dikomputasi sebagai berikut:
a. Meter/Gauge : $2^{16}=65.536$ rule koneksi
b. Audio : $: 2^{13}=8.192$ rule koneksi,
c. DoorLock : $2^{5}=32$ rule koneksi,
d. LightingInterior : $2^{4}=16$ rule koneksi,
e. AC/Air Conditioner : $2^{7}=128$ rule koneksi,
f. Wiper/ Washer: $2^{9}=512$ rule koneksi,
g. Mirror: $2^{2}=4$ rule koneksi,
h. Lighting Exterior : $2^{23}=8.388 .608$ rule koneksi,
i. Horn: $2^{1}=2$ rule koneksi.

\subsection{Model Sistem Pakar}

Dalam mendisain sistem pakar untuk mendeteksi tingkat kerusakan sistem kelistrikan pada mobil Toyota Avanza digunakan metode Fuzzy Inference System (FIS) Mamdani dengan membandingkan 3 (tiga) model membership function yaitu model Gaussian, Triangular dan Trapezoid. Berikut penjelasan rincinya.

a. Komponen FIS Mamdani

\section{1) FIS Editor}

Untuk menampilkan FIS Editor, kriteria dan indikator yang sudah dianalisa sebelumnya dijadikan variabel dalam menentukan penilaian terhadap gejala-gejala pada kerusakan sistem kelistrikan. FIS Editor untuk model Gaussian, Trapezoid dan Triangular untuk kasus yang dibahas diperlihat pada Gambar 4, Gambar 5, Gambar 6. 


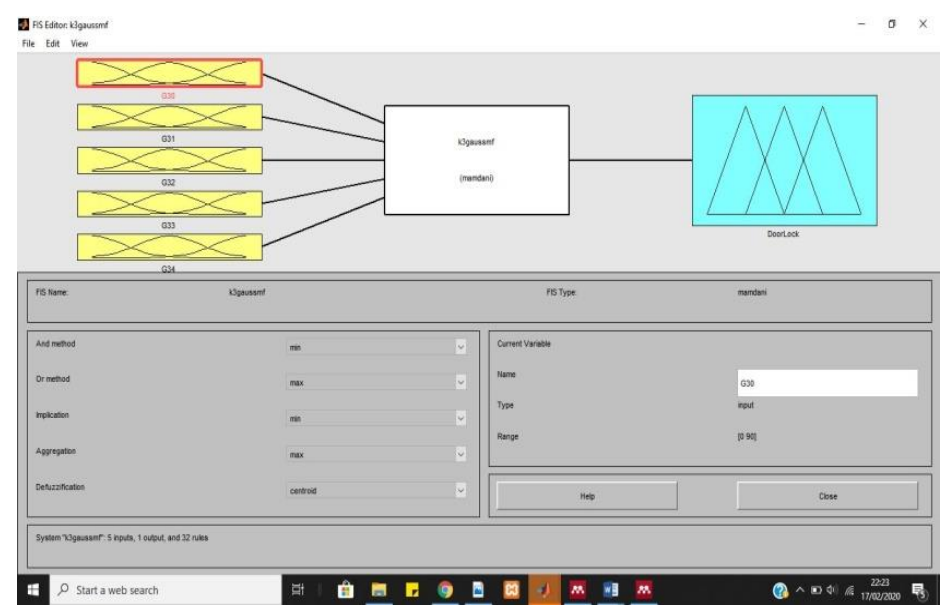

Gambar 4. FIS Editor Mamdani untuk model Gaussian

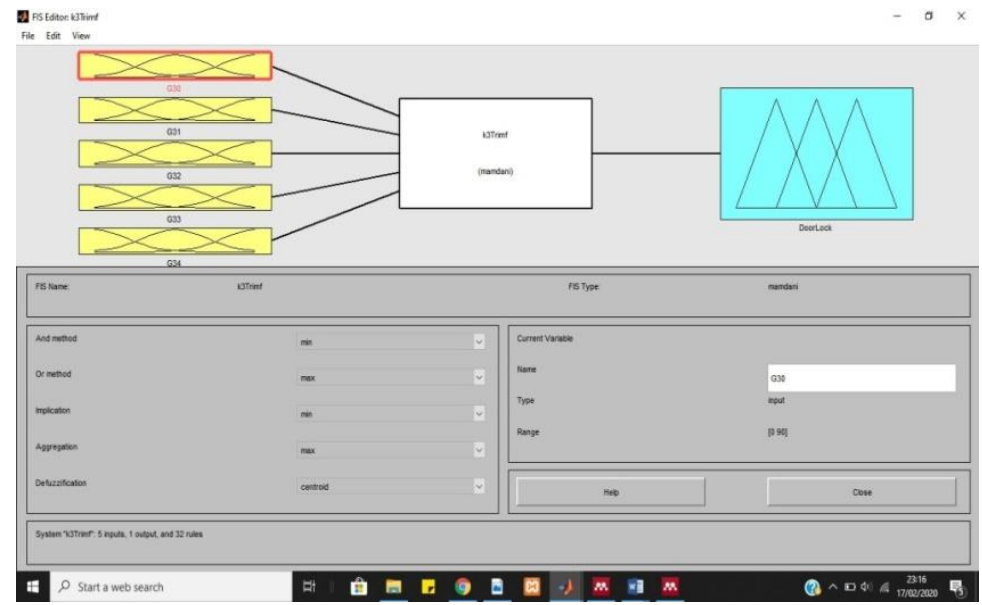

Gambar 5 FIS Editor Mamdani untuk model Trapezoid

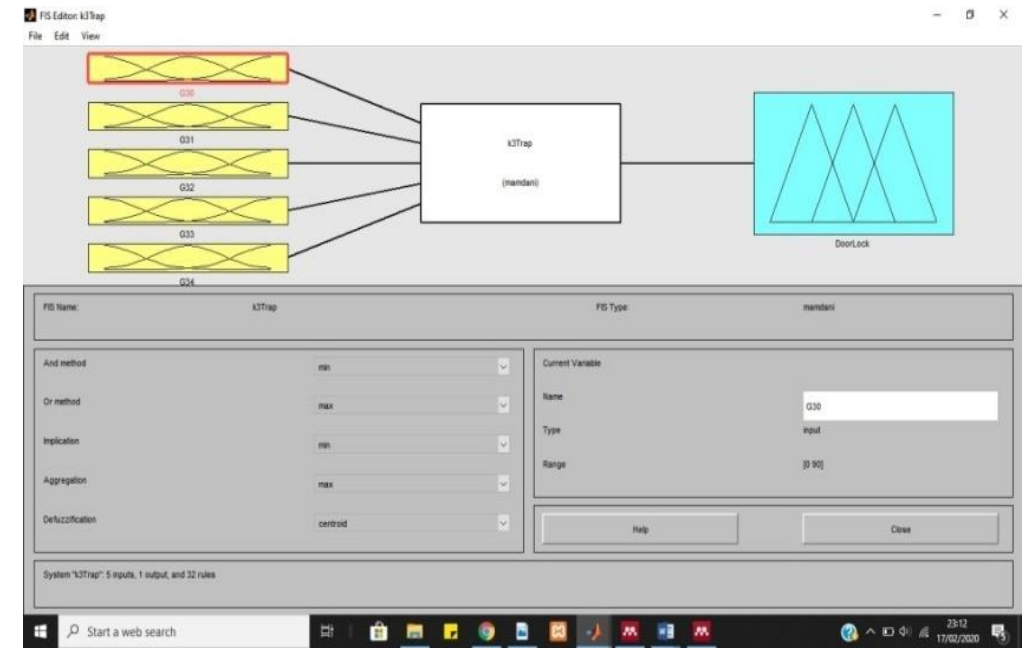

Gambar 6. FIS Editor Mamdani untuk model Triangular 


\section{2) Membership Function Editor}

Salah satu cara yang dapat digunakan untuk mendapatkan nilai keanggotaan adalah dengan melalui pendekatan fungsi. Ada beberapa fungsi yang dapat digunakan diantaranya yaitu:

a) Representasi Kurva Gaussian

Representasi kurva Gaussian memiliki bentuk yang hampir sama dengan kurva Segitiga dengan permukaan yang tumpul. Biasanya kurva Gaussian digunakan untuk mengolah data-data yang acak Representasi kurva Gaussian seperti ditunjukkan pada Gambar 7.

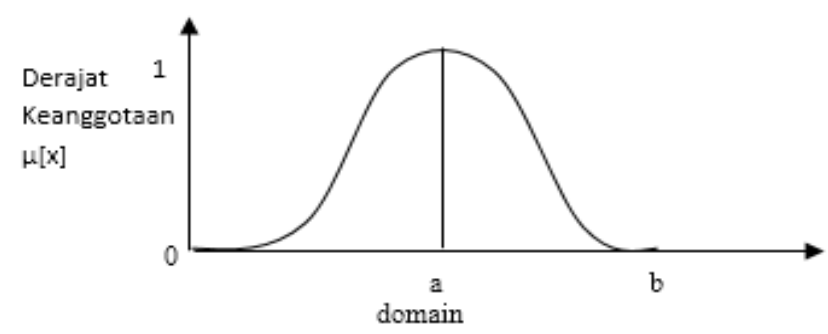

Gambar 7. Representasi Kurva Gaussian.

Fungsi keanggotaan fuzzy dapat dilihat pada Persamaan 1 :

$$
\mu[x]=e^{-\left(\frac{x-y}{b}\right)^{2}}
$$

Keterangan :

$a=$ nilai domain pada pusat kurva

$b=$ lebar kurva

$x=$ nilai input yang akan di ubah ke dalam bilangan fuzzy

b) Representasi Kurva Segitiga

Kurva Segitiga pada dasarnya merupakan gabungan antara dua garis (linear) seperti terlihat pada Gambar 8. Represetasi Kurva Segitiga, pemetaan input ke derajat keanggotaannya digambarkan dengan bentuk segitiga dimana pada dasarnya bentuk segitiga tersebut gabungan antara 2 garis (linear). Nilai-nilai di sekitar b memiliki derajat keanggotaan turun yang cukup tajam (menjauhi 1).

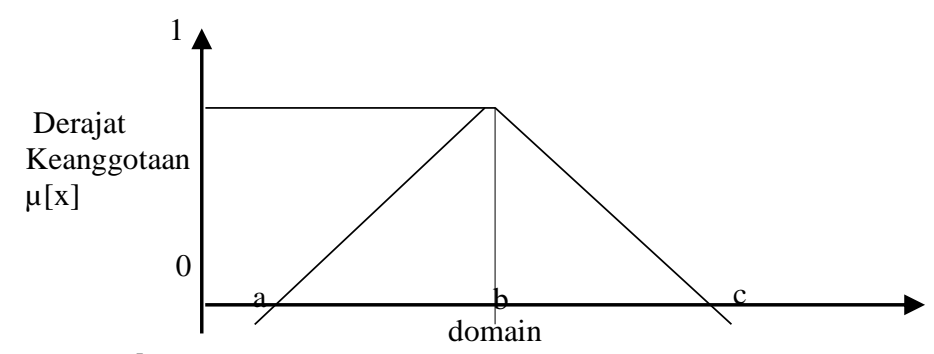

Gambar 8. Representasi Kurva Segitiga. 
Fungsi Keanggotaan fuzzy dapat dilihat pada Persamaan 2 :

$$
\mu[x]=\left\{\begin{array}{l}
\frac{0 ; x \leq a \text { atau } x \geq c}{(x-a)} ; b \leq x \leq c \\
\frac{(b-a)}{(c-x)} ; a \leq x \leq b
\end{array}\right.
$$

Keterangan:

$a=$ nilai domain terkecil yang mempunyai derajat keanggotaan nol

$b=$ nilai domain yang mempunyai derajat keanggotaan satu

$c=$ nilai domain terbesar yang mempunyai derajat keanggotaan nol

$x=$ nilai input yang akan di ubah ke dalam bilangan fuzzy

c) Representasi Kurva Trapesium

Kurva Trapesium pada dasarnya seperti bentuk segitiga karena merupakan gabungan antara dua garis (linier), hanya saja ada beberapa titik yang memiliki nilai keanggotaan 1. Representasi kurva trapesium ditunjukkan pada Gambar 9. Representasi trapesium ini memiliki 4 parameter $\{a, b, c, d\}$.

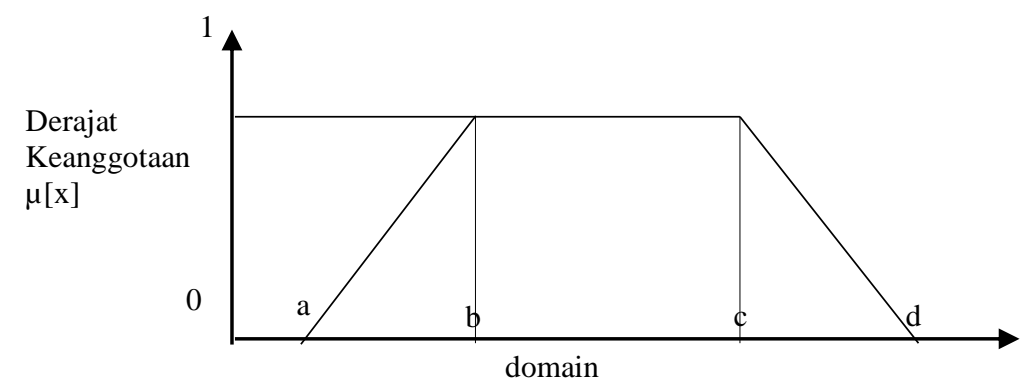

Gambar 9. Representasi Trapesium.

Fungsi Keanggotaan fuzzy dapat dilihat pada Persamaan 3 :

$$
\mu[x]=\left\{\begin{array}{c}
\frac{0 ; x \leq a \text { atau } x \geq d}{(x-a)} \\
\frac{(b-a)}{1 ; b \leq x \leq c} ; a \leq x \leq b \\
\frac{(d-x)}{(d-c)} ; x \geq d
\end{array}\right.
$$

Keterangan:

$a=$ nilai domain terkecil yang mempunyai derajat keanggotaan nol

$b=$ nilai domain terkecil yang mempunyai derajat keanggotaan satu

$c=$ nilai domain terbesar yang mempunyai derajat keanggotaan satu

$d=$ nilai domain terbesar yang mempunyai derajat keanggotaan nol

$x=$ nilai input yang akan diubah ke dalam bilangan fuzzy 
Kumpulan jurnaL Ilmu Komputer (KLIK)

Volume 8, No 1 (2021)

ISSN: 2406-7857
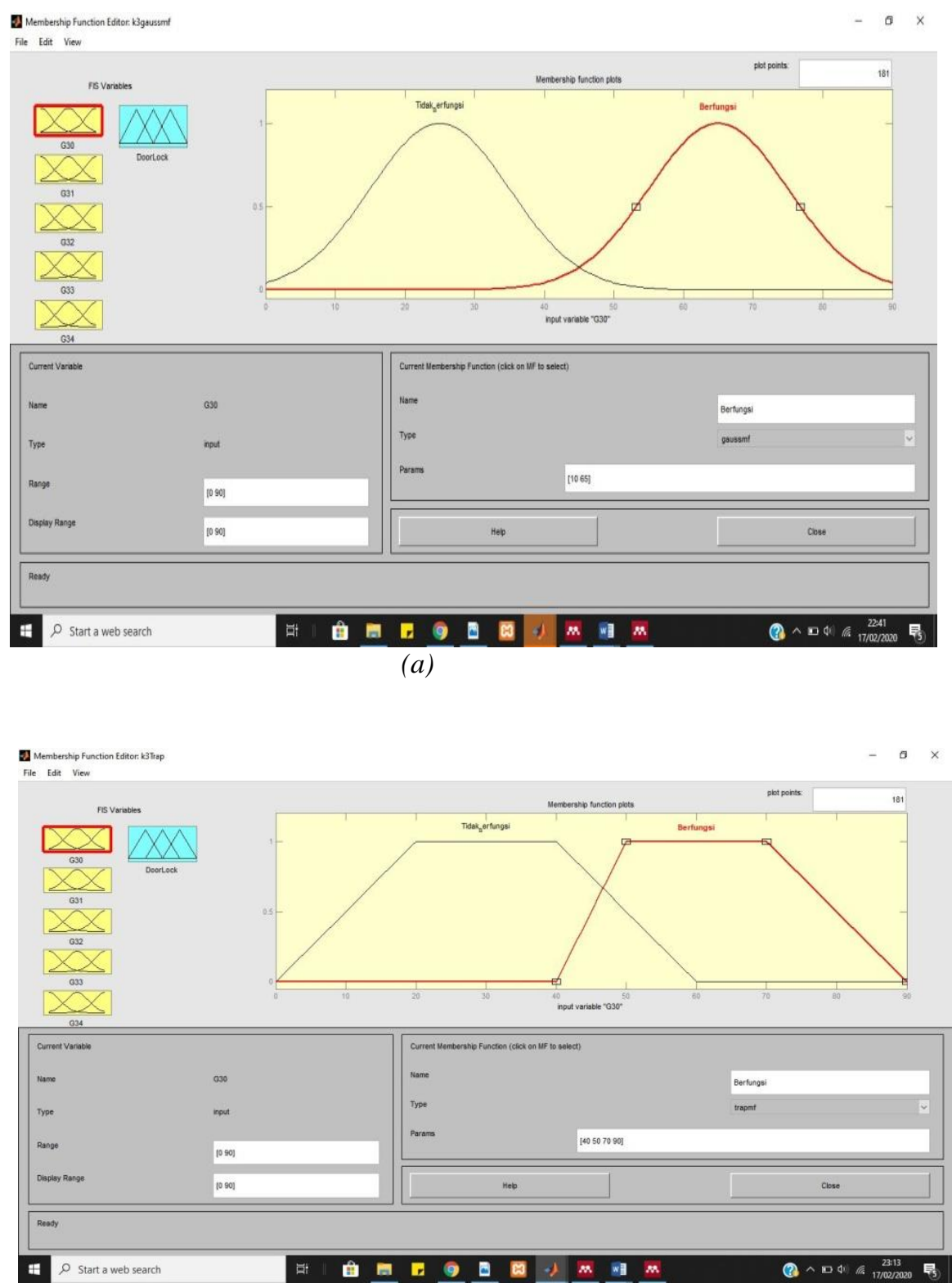

(b) 


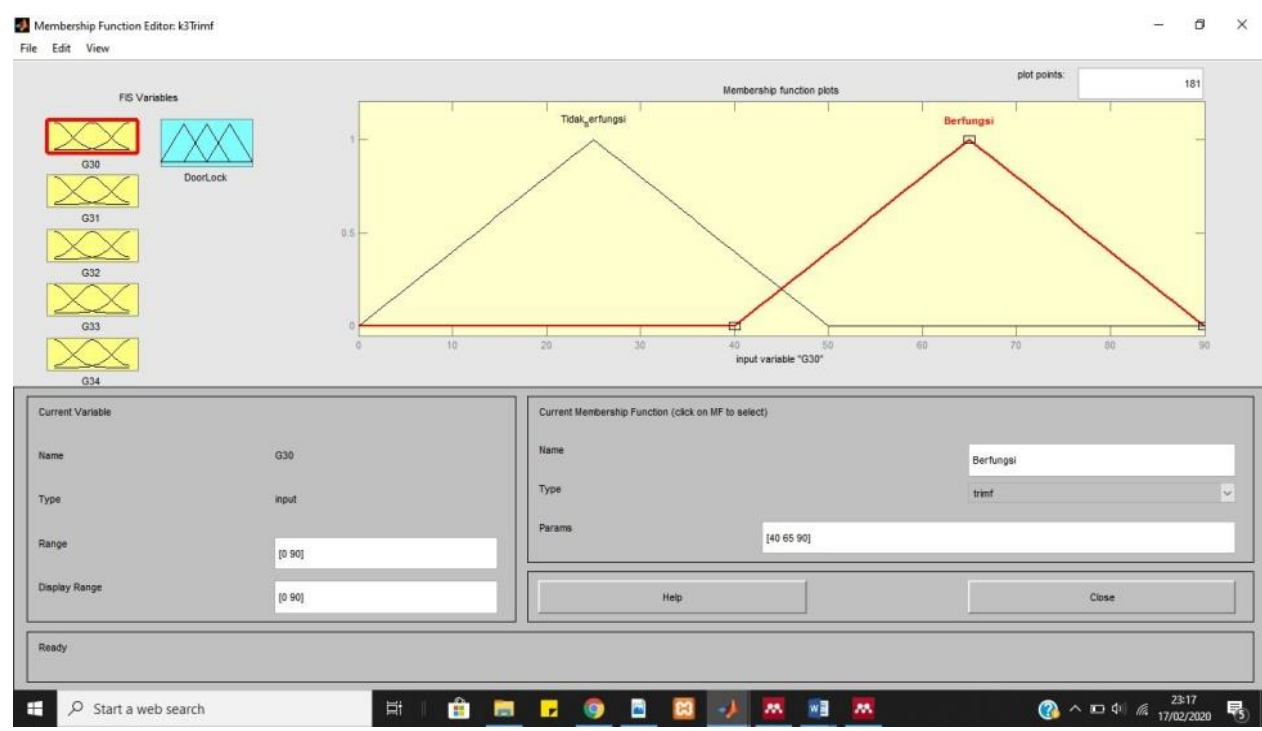

(c)

Gambar 10. Membership Function untuk model Gaussian (a), Trapezoid (b), dan Triangular (c).

\section{3) Rule Editor}

Tiap aturan merupakan implikasi, setelah himpunan fuzzy dibentuk, maka dilakukan pembentukan aturan-aturan fuzzy. Pada tahapan ini dibuat daftar rule sesuai dengan kebutuhan dan rule yang digunakan adalah rule default sehingga secara otomatis rule dibuat oleh ANFIS. Dapat dicatat bahwa rule yang berlaku untuk masing-masing model adalah sama untuk setiap kerusakan. Salah satu tampilan Rule Editor diperlihatkan dalam Gambar 11.

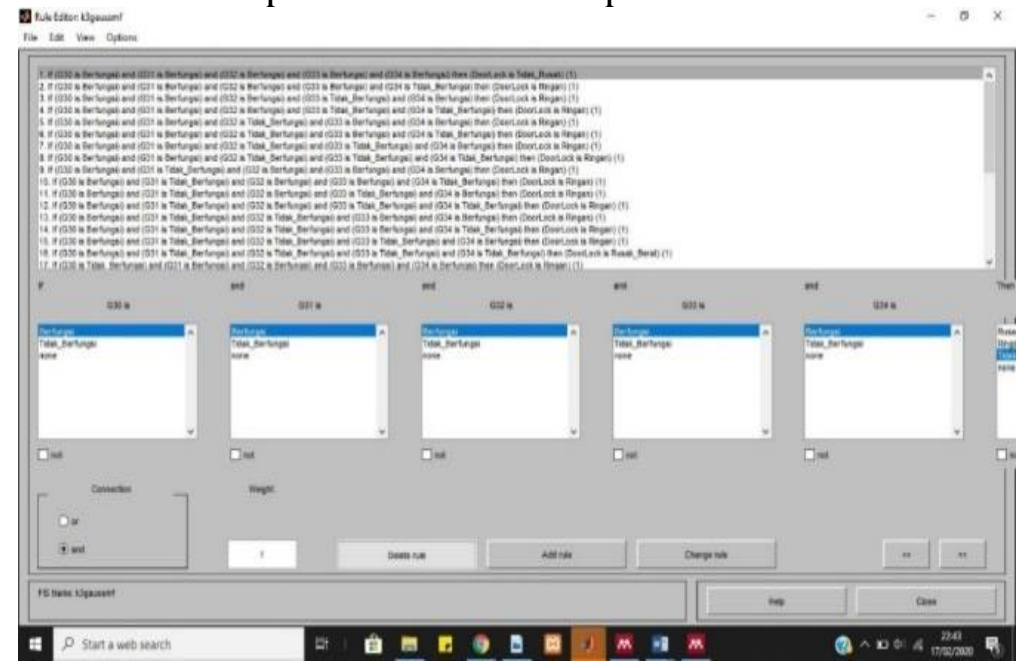

Gambar 11. Tampilan Rule Editor Model Gaussian 


\section{4) Rule Viewer}

Rule viewer mengimplementasikan fungsi keanggotaan yang telah didefinisikan pada rules yang telah dibuat. Rule Viewer digunakan untuk melihat alur penalaran fuzzy pada sistem yang berisi pemetaan input yang diberikan, aplikasi operator dan fungsi implikasi tegas pada defuzzifikasi.

\section{5) Surface Viewer}

Surface viewer berfungsi untuk melihat grafik tiga dimensi pemetaan antara variabel-variabel output. Dalam Gambar 12 diperlihatkan bentuk Surface Viewer untuk kasus yang dibahas dengan menggunakan model Gaussian, Trapezoid dan Triangular.

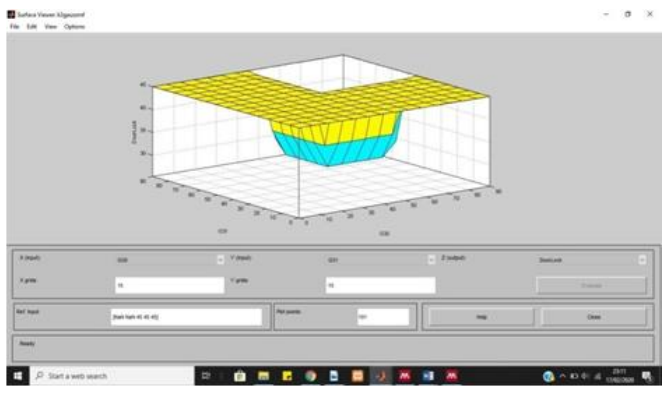

(a)

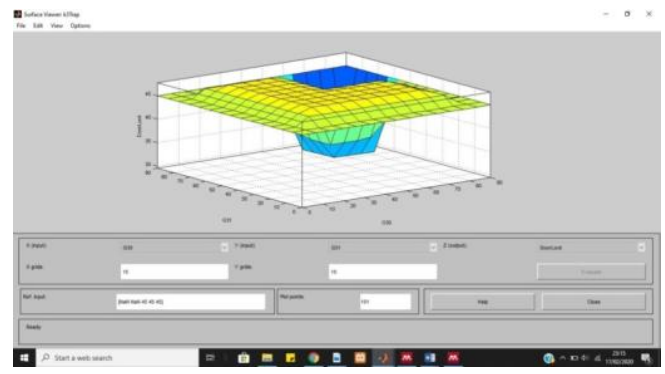

(b)

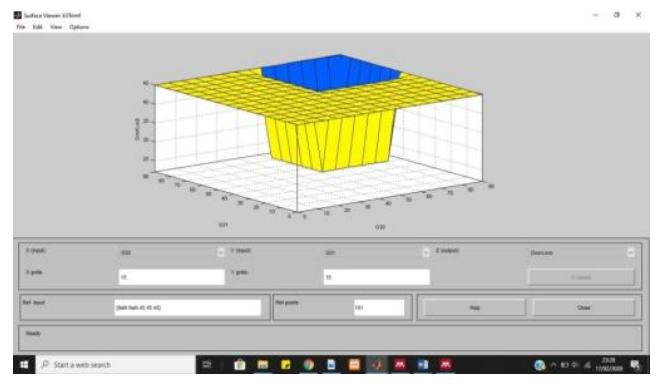

(c)

Gambar 12. Surface Viewer untuk model Gaussian (a), Trapezoid (b), dan Triangular (c). 


\subsection{Implementasi Disain Sistem}

Pada setiap halaman terdapat lima menu yang dapat dioperasikan, yaitu Beranda, Deteksi Kerusakan, Bantuan, Tentang, dan Keluar. Untuk button keluar tidak ada interface karena saat button di klik maka sistem langsung keluar. Pada halaman Deteksi Kerusakan, setiap kerusakan yang ingin dideteksi memiliki satu atau lebih pertanyaan berkenaan dengan gejala dari kerusakan yang dialami. Setiap pertanyaan memiliki masukan (input) berupa nilai yang telah ditentukan sebelumnya. Pada Gambar 13 diperlihatkan tampilan sebagian interface dari halaman Deteksi Kerusakan.

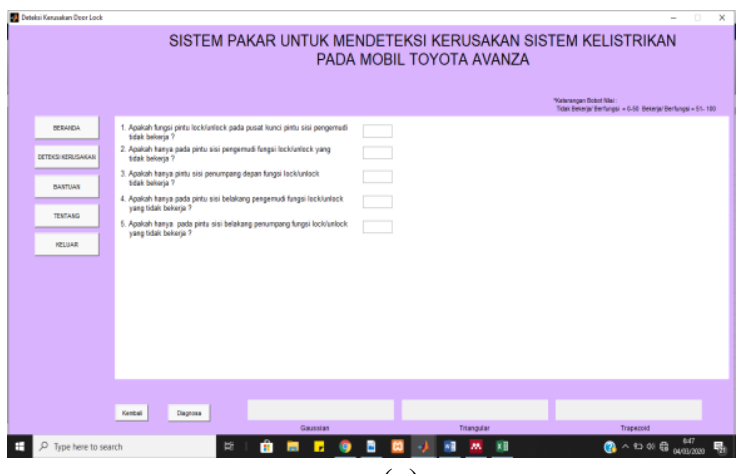

(a)

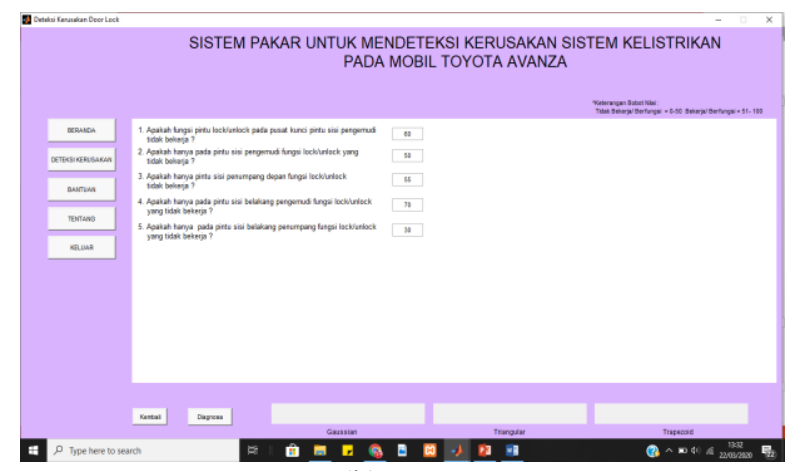

(b)

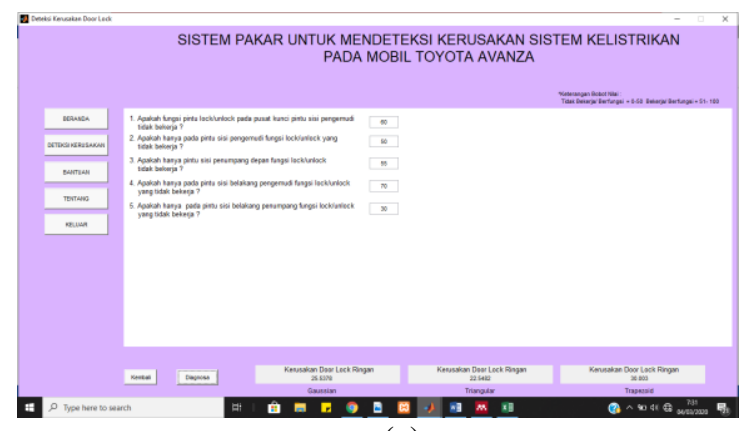

(c)

Gambar 13. Interface Halaman Deteksi Kerusakan untuk input (a dan b), dan untuk output (c).

\subsection{Pengujian Sistem}

Pada pengujian sistem ini dilakukan oleh pakar dibidang otomotif untuk menguji dari 3 model membership function yaitu, Gaussian, Triangular dan Trapezoid yang outputnya sesuai atau mendeketi dengan hasil outputpakar. Hasil pengujian sistem dapat dilihat pada Tabel 2.

Tabel 2. Pengujian Sistem Pakar Untuk Mendeteksi Tingkat Kerusakan Sistem Kelistrikan Pada Mobil Toyota Avanza.

\begin{tabular}{llllll}
\hline No. & Nama Kerusakan & Gaussian & Triangular & Trapezoid & Hasil Pakar \\
\hline 1. & Meter $/$ Gauge & Berat (63.361) & Ringan (45) & Ringan (45) & Berat (80) \\
2. & Audio & Berat (63.361) & Ringan (45) & Ringan (45) & Ringan (20) \\
3. & Door Lock & Berat (63.361) & Ringan (45) & Ringan (45) & Berat (80)
\end{tabular}




\begin{tabular}{|c|c|c|c|c|c|}
\hline No. & Nama Kerusakan & Gaussian & Triangular & Trapezoid & Hasil Pakar \\
\hline 4. & Lighting Interior & $\begin{array}{l}\text { Ringan } \\
(40.937)\end{array}$ & $\begin{array}{l}\text { Tidak Terjadi } \\
\text { Kerusakan }(0)\end{array}$ & $\begin{array}{l}\text { Ringan } \\
(43.915)\end{array}$ & Ringan (20) \\
\hline 5. & AC (Air Conditioner) & Ringan (45) & Ringan (44.941) & $\begin{array}{l}\text { Ringan } \\
(47.760)\end{array}$ & Ringan (20) \\
\hline 6. & Window & $\begin{array}{l}\text { Ringan } \\
(22.364)\end{array}$ & Ringan (22. 548 & $\begin{array}{l}\text { Ringan } \\
(44.203)\end{array}$ & Ringan (20) \\
\hline 7. & Mirror & Berat (63.361) & Ringan (45) & Ringan (45) & Berat (80) \\
\hline 8. & Wiper/Washer & $\begin{array}{l}\text { Ringan } \\
(57.104)\end{array}$ & Ringan (45) & Ringan (45) & Berat (80) \\
\hline 9. & Lighting Exterior & Berat (63.361) & Ringan (45) & Ringan (45) & Ringan (80) \\
\hline 10. & Horn & $\begin{array}{l}\text { Ringan } \\
(53.288)\end{array}$ & $\begin{array}{l}\text { Tidak Terjadi } \\
\text { Kerusakan }(0)\end{array}$ & Berat (61.105) & Ringan (20) \\
\hline
\end{tabular}

Hasil yang diperoleh dari pengujian di atas dengan membandingkan 3 model membership function dan hasil pakar diperoleh nilai yang berbeda-beda. Bobot nilai yang diberikan oleh model sistem yaitu jika Tidak Terjadi Kerusakan nilainya adalah 0, jika Kerusakan Ringan nilainya dari 1 - 60 dan Kerusakan Berat nilainya dari 61 - 100. Kemudian untuk bobot nilai dari pakar jika Kerusakan Ringan nilainya adalah 20 , bobot Kerusakan Berat nilainya adalah 80 dan Tidak Terjadi Kerusakan adalah 0. Perbandingan hasil output tersebut yang mendekati nilai bobot pakar terdapat pada model Gaussian, karena dari pengujian terdapat 8 dari 10 kerusakan yang nilai output model Gaussian memperlihatkan hasil nilai hampiran galat yang rendah terhadap nilai bobot pakar, 1 dari 10 kerusakan yang nilai output model Triangular dan Trapezoid yang mendekati nilai bobot pakar, dan 1 dari 10 kerusakan yang nilai output model Triangular yang mendekati nilai bobot pakar dan akurasi .

\section{KESIMPULAN}

Dari bagian hasil dan pembahasan yang telah dikemukakan sebelumnya dapat disimpulkan bahwa untuk membangun sistem informasi berbasis ANFIS (Adaptive Neuro- fuzzy inference system) khususnya FISM dapat dilakukan terhadap pendeteksian kerusakan sistem kelistrikan pada kendaraan mobil khususnya Toyota Avanza. Selain itu, penggunaan sistem pakar untuk kasus yang dibahas menunjukan bahwa model membership function Gaussian lebih akurat (mencapai 85\%) dalam perkiraan kerusakan sistem kelistrikan yang dianalisa.

\section{DAFTAR PUSTAKA}

[1] Cnnindonesia.com. Penjualan Kendaraan Meningkat, Toyota Pimpin Pasar Roda Empat. Diakses pada 25 Desember 2018, dari https://www.cnnindonesia.com/teknologi/20180628072044-384- 
309713/penjualan-kendaraan-meningkat-toyota-pimpin-pasar-rodaempat. (2018, 28 Juni)

[2] Kamase, J. Influence Factors Cultural Factors Social Factors Characteristic Individual And Psychological Factor On The Decision Purchase Of Car Toyota Avanza In Makassar. Makassar: IOSR Journal of Business and Management, Vol 19(05), 99-104. 2017

[3] Harsono, R. The Impact of Marketing Mix ( $4 P^{\prime} S$ ) on Customer Loyalty Towards Toyota Avanza. Surabaya: iBuss Management, Vol 4(1), 1-7. 2016

[4] Shen, C., Shan, P., \& Gao, T. A comprehensive overview of hybrid electric vehicles. International Journal of Vehicular Technology. Volume 2011, Article ID 571683, 7 pages.2011

[5] KM, X. V, \& Raju, I. Hybrid Electric Vehicles. International Journal of Engineering Trends and Technology (IJETT), Vol 50(2). 2017

[6] Andriani, A. Pemrograman Sistem Pakar (MediaKom (ed.); cet. 1). Yogyakarta: PT BUKU SERU. 2017

[7] Rosnelly, R. Sistem Pakar Konsep dan Teori (P. Y. Jati (ed.); 1st ed.). Yogyakarta: ANDI. 2012

[8] Hayadi, B. H. Sistem Pakar (1st ed.). Yogyakarta: Deepublish. 2018

[9] Irwansyah, E., \& Faisal, M. Advanced Clustering: Teori dan Aplikasi. Banda Aceh: Deepublish. 2015

[10] Sujawarta. Buku Ajar Sistem Fuzzy dan Aplikasinya. Semarang: Deepublish. 2014

[11] Kusumadewi, S., \& Hartati, S. Neuro-Fuzzy Integrasi Sistem Fuzzy Jaringan Syaraf. Yogyakarta: Graha Ilmu. 2010

[12] Kusumadewi, S., \& Purnomo, H. Aplikasi Logika Fuzzy Untuk Pendukung Keputusan. Yogyakarta: Graha Ilmu. 2010

[13] Kamsyakawuni, A., Gernowo, R., \& Sarwoko, E. A. Aplikasi Sistem Pakar untuk Diagnosa Penyakit Hipertiroid dengan Metode Inferensi Fuzzy Mamdani. Jurnal Sistem Informasi Bisnis, 2(2), 58-66. 2012

[14] Ismawati, D., Syauqy, D., \& Prasetio, B. H. Perbandingan Jumlah Membership Dan Model Fuzzy Terhadap Perubahan Suhu Pada Inkubator Penetas Telur. Malang: Universitas Brawijaya, Vol 1(6), 476-485. 2017 